\title{
Matter transfer during virgin olive oil elaboration
}

\author{
By Carlos Gómez Herrera
}

\author{
Instituto de la Grasa \\ Avenida Padre García Tejero, 4 \\ 41012 Sevilla
}

\section{RESUMEN}

Transferencias de materias durante la elaboración del aceite de oliva virgen

Durante la elaboración del aceite de oliva virgen (cuyas principales etapas son molturación, batido y centrifugación) se producen transferencias de diversos componentes menores a los triacilgliceroles originalmente presentes en los glóbulos oleosos de las células del mesocarpio de los frutos. Estos componentes menores son especies químicas presentes en las aceitunas, así como especies resultantes de procesos químicos o enzimáticos que se producen en la pasta a partir de la molturación. En este artículo se estudian diversos tipos de componentes menores transferibles, as como aquellos parámetros que afectan sus velocidades de transferencia.Se discuten las variaciones geométricas y físicas de las regiones interfaciales situadas entre el aceite y los otros sistemas en contacto con el mismo. Estos sistemas son el agua de vegetación, los componentes de la pulpa y los fragmentos de endocarpio leñoso de las aceitunas, así como el aire y el utillaje de almazara.

Este artículo termina con algunas consideraciones sobre las mejoras en los aceites de oliva virgen ya elaborados, conseguidas controlando transferencias de "componentes menores".

PALABRAS CLAVE: Artículo de información - Componentes menores - Elaboración de aceite de oliva virgen Región interfacial - Transferencia de materia - Velocidad de transferencia.

\section{SUMMARY}

\section{Matter transfer during virgin olive oil elaboration}

In the course of the process of elaboration of virgin olive oil (whose main stages are crushing, malaxation and centrifugation) the transfer of several minor components to the triacylglycerol constituent of the oily globules originally present in the cells of the fruit mesocarp is produced. Such minor components are chemical species present in the olive fruits, as well as those resulting from chemical or enzymatic processes which take place in the olive paste upon crushing. In this paper several types of transferable minor components, as well as those parameters affecting the rates of transfer are studied.Geometric and physical variations of interfacial regions between the oil and other systems in contact with it are discussed. These systems are olive vegetation water, olive pulp components, and fragments of the woody endocarp, as well as the atmospheric air and the tools and equipment of the oil mill.

This article concludes with some considerations about the improvements of virgin olive oils achieved by controlling the transfer of minor components.
KEY-WORDS: Interfacial region - Matter transfer - Minor components - Review paper - Transfer rate - Virgin olive oil elaboration

\section{PREAMBLE}

This review paper is based on the work of several research teams, mainly Spanish and Italian ones, carried out over the last decades. The substitution of discontinuous pressure operations by continuous centrifugation processes in olive-oil mills demands an incessant increase of a thorough study of matter transfer during the elaboration of virgin olive oil. Transfer takes place between the oil located in the parenchyma cells of the olive fruit mesocarp and other substances which come into contact with it upon olive fruit crushing and the subsequent steps involved in the elaboration of virgin olive oil, until the oil is finally bottled for marketing. The main reason for such demand is described below.

Some decades ago all olive-oil mills worked with the traditional pressure system, but nowadays the continuous centrifugation system is predominant. The set of transfers produced during a pressure operation, facilitated by the effects of strong shearing between the components of crushed paste, and with the wrinkled surface of the filtering plastic mats, is complete. On the other hand, when the paste is submitted to continuous centrifugation, without undergoing any significant shearing effects, the set of transfers is not complete. Undoubtedly the pomace resulting from the press system (the socalled orujo, which is the olive paste quite de-oiled and desiccated) is always much more "exhausted" than the paste produced by the two-phase decanter centrifugation system (called alperujo, which is only partially de-oiled).

This paper should not be considered an exhaustive monograph on the subject, but a personal view on a series of matter transfer processes affected by diverse factors, which depend on the progress in the design of oil mill equipment and tools for crushing, malaxation and continuous centrifugation.

In the vast bibliography examined (several tens of articles per year over three decades) numerous references to detailed aspects related to these 
transfers of matter are found. To include all the bibliographical references would have produced a very long publication, with a text continuously interrupted by quotations between parenthesis and numerous pages of bibliography.

Following the criterion of similar publications about personal perspectives, references listed at the end of this paper have been selected according to a "minimal principle" (least possible in size). The rule adopted has been to include references to recent publications and not necessarily to the original basic work. From the references given, the interested reader should be able to track the original literature.

\section{INTRODUCTION}

The cellular oil contained in the parenchyma cells of the mesocarp of olive fruits before their crushing is a system that can easily exchange chemical species with most other systems which come into contact with it. This behavior is due to its chemical composition and its physical properties (especially the rheological ones) which are very different from those of the other components of crushed olive paste.

The production of virgin olive oil can not be compared to a simple extraction and separation of cellular oil, but with a genuine and complex set of enzymatic and physicochemical processes. "Elaboration" was the expression used by Dr. José Manuel Martínez Suárez, a distinguished researcher who was an expert in olive-oil mill operations and olive oil quality, to define the transformation of cellular oil into virgin olive oil. The mixtures of cellular oil and chemical species which are incorporated into it when the oily mesocarp cells are broken down and until virgin olive oil is finally bottled for marketing, are designated in this paper with the expression oil in elaboration. The chemical species transforming the cellular oil into virgin olive oil in the course on a normal elaboration process are named minor components.

Two main objectives are pursued in all the methods of virgin olive oil elaboration:

a) To achieve the coalescence of most of the oil in elaboration droplets to constitute a continuous oily phase of virgin olive oil.

b) To achieve a resulting oil, prior to its processing to take part of a defined marketing lot, contains concentrations of minor components which best suits the composition that the experts responsible for that process find most desirable. Not everything described in this paper about chemical species transfer in which oil in elaboration intervenes can be applied to the small globules coming from mesocarp cells or formed by emulsifying during crushing or malaxation. Such globules are protected by lipoprotein membranes, which hamper all kind of transfer through them.
Figure 1 is a very schematic representation of transfers into the cellular oil of chemical species originally present in the mesocarp cells or produced in the olive paste as a result of chemical or enzymatic processes occurring in it. Scheme 1 of this figure corresponds to cellular oil droplets, already separated from the interior of mesocarp cells. Scheme 2 represents other components of the paste. Scheme 3 shows the paste during malaxation. Scheme 4 shows separation by physical means of the oil in elaboration contained in the paste after malaxation. Finally, scheme 5 represents the mixture of cellular oil and some components of the paste which have been incorporated into it by transfers.

In general, the extent of the transfers of the chemical species which take placed in the interfacial regions between a continuous or dropshaped oily system, on one hand, and a very heterogeneous group of aqueous-organic systems on the other, depends basically on the physical structure and chemical composition of all the systems, together with the temperature and duration of contact, as well as the extension, curvature and renovation of the interfacial regions. Partition equilibrium for a specific chemical species will be reached if the time of contact is long enough.

In the operations carried out in olive-oil mills, the transfers of interest are those taking place between the oil in elaboration and the rest of macroscopic systems in the paste. Such systems are: pulp, vegetation water and fragments of woody endocarp. There are also transfers with the systems of the environment surrounding the paste (air, water, surfaces of equipment and tools, etc.).

\section{OLIVE PASTE STRUCTURE}

To facilitate the study of transfers of chemical species taking place during the elaboration of olive oil, a hypothetical simplified structure of the olive paste is proposed.

When the crushing of the olives is finished, the experts at the olive-oil mills distinguish the following systems in the olive pastes:

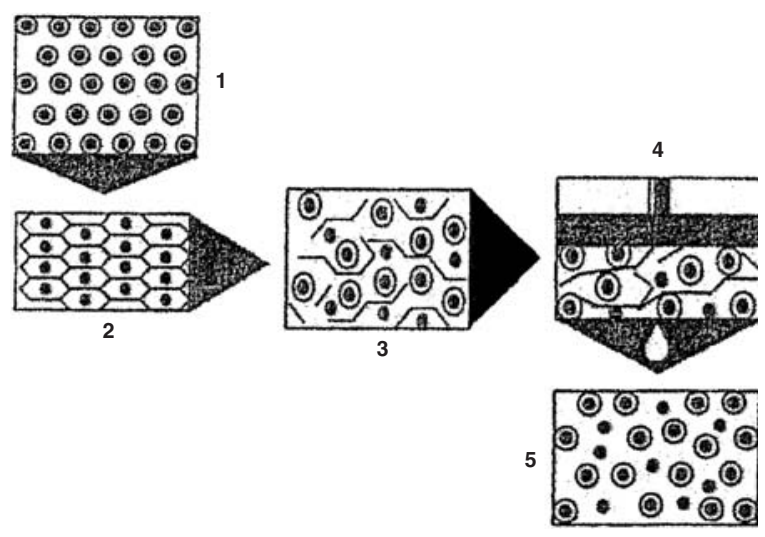

Figure 1

Scheme of the steps of transfers to the oil in elaboration of chemical species present in the ground paste. 
A. Free oil (aceite suelto)

B. Free olive vegetation water ("alpechín")

C. Fragments of woody endocarp ("huesos")

D. Pulp (pulpa)

"Free oil" is formed by the portions of olive in elaboration which are left with almost no retention effects by the other systems of the paste before it is placed in the oil separation device (press with filtration mats, percolator, centrifugal decanter). Such portions are big drops and non-spherical pockets of oil in a continuous phase.

The "alpechín" consists of a continuous aqueous phase derived from the olive vegetation water in contact with the other systems in the paste. It contains a certain amount of oil in the form of droplets of various sizes, among which small globules of cellular oil protected by lipoprotein membranes are found.

The free oily must is formed by the free oil and the "alpechín".

The "huesos" are fragments of woody endocarp formed during the crushing of olives. With a size in the range of $1 \mathrm{~mm}$ to $3 \mathrm{~mm}$, they are of a hydrophilic nature and appear intercalated between the other systems of the paste.

The pulp is initially formed by a disperse system in the free oily must of all the fragments of epicarp, mesocarp and seed as they are found when the crushing of olives is finished. It contains disperse gaseous bubbles originally present inside the fruits or that have been incorporated during oil elaboration.

The pulp can be considered a mixture of two systems with very different characteristics and behaviors: the lipophilic laminar pulp and the pseudo-colloidal pulp.

The lipophilic laminar pulp is constituted mainly of pieces of the fruit peel and other epicarp tissues, as well as flexible and laminar fragments, which derive from mesocarp and seed tissues. The behavior of this system, due to its low content in water, cannot be compared to that of a colloidal system, especially in regard to its rheological and physicochemical characteristics.

The pseudo-colloidal pulp consists of an ensemble of numerous fragments of tiny size, deriving from the crushing of the mesocarp, in a state similar to that of a pseudo-colloidal gel. These fragments do not flow under their own weight. It also contains fragments of the crushed seeds and is characterized by its high water content.

(A pseudo-colloid is defined as a disperse system of colloidal species where each colloidal unit has an adsorbed component by which it can be detected or measured, as opposed to a pure colloid, which does not have adsorbed material).

In this article the small portions of the pseudo colloidal pulp are designated as micro-pseudo-gel, and each one presents three main components:

a. A fibrous reticular framework, which is mostly made up of fragments of cellular structures deriving from the mesocarp basically composed of polysaccharides and proteins with a high content in imbibing water. b. The cellular oil globules, of different sizes, situated in the interior of the framework.

c. Portions of the olive vegetation water, occluded in the spaces situated between the framework and the globules.

The components $b$ and $c$ of all micro-pseudogels that form the pseudo-colloidal pulp of an olive paste, constitute the occluded must.

One of the important effects of malaxation is the release of the cellular oil globules and portions of occluded vegetation water from the interior of the micro-pseudo-gels. Such globules, together with the water, are incorporated to the free oily must.

Certain processes, catalyzed by enzymes present in the olive fruit, and which act on the micro-pseudo-gel framework, can significantly change the behavior of pseudo-colloidal pulp during malaxation and subsequent separation of oil in elaboration.

Figure 2 shows a simplified scheme of a laminar cut of the olive paste structure at the end of the crushing step. In this figure, as well as in the subsequent schemes of this article, the systems proposed for an olive paste are represented in the following way:

a) The fibrous reticular framework of the pseudo-colloidal pulp corresponds to the zones with parallel stripes in direct contact.

b) The small droplets of cellular oil situated inside this framework correspond to the circles almost completely surrounded by striped zones.

c) The portions of occluded vegetation water, between the framework and the oil droplets, correspond to the blank spaces situated between the striped zones and the circles.

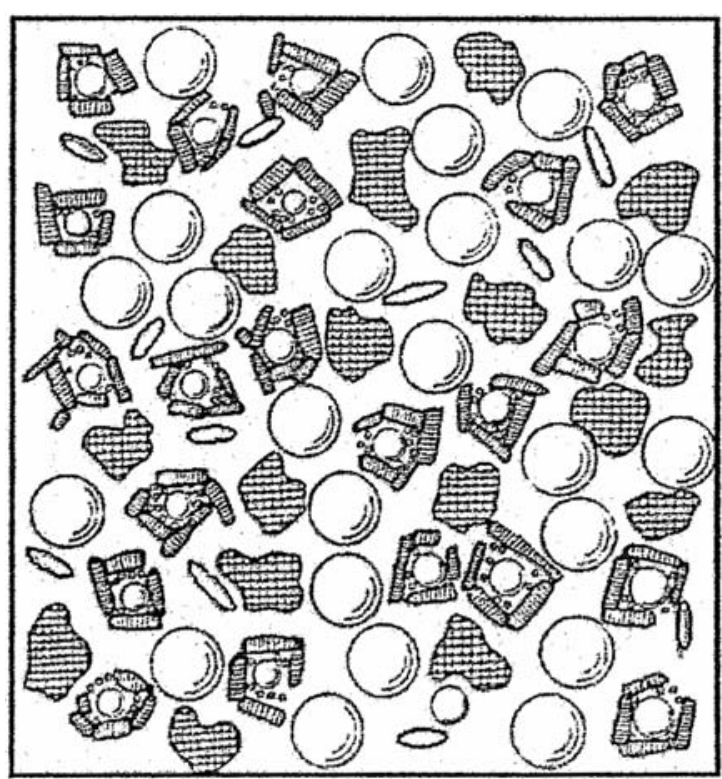

Figure 2

Simplified scheme of paste structure after crushing. 
d) The portions of lipophilic laminar pulp are represented by the tapering surfaces with a blank inside.

e) The fragments of woody endocarp ("huesos") correspond to the gridded zones.

f) The big free oil drops are represented by the big isolated circles.

g) The aqueous phase of free olive vegetation water ("alpechín") corresponds to the continuous region that fills the background.

Neither the non-spherical pockets of free oil nor the gaseous bubbles are represented in the schemes.

To facilitate the observation of figure 2 , systems in the paste other than the continuous phase of vegetation water appear without contact between them.

\section{TRANSFERS OF CHEMICAL SPECIES}

On first approach, it can be accepted that the instantaneous rate of transfer of a chemical species between a homogeneous essentially liquid oily system (free oil) and a heterogeneous set of systems predominantly of an aqueous nature (consisting of free vegetation water and pulp), depends on the three following parameters:

Parameter A - The dimensions and other geometrical characteristics of the interfacial region that separate the free oil from the other paste systems. The thickness of the interfacial region is determined by the thickness of the zone within which the behavior of each system is affected by the proximity of the other system.

Parameter B - The potentiality factor of the chemical species, defined by the difference of free energies of such species in each of the systems between which the transfer takes place. On first approach, concentrations can be considered proportional to free energy.

Parameter $\mathrm{C}-\mathrm{A}$ resistance coefficient of the chemical species depending on its diffusion velocities through each one of the two systems, as well as on the conditions on which the species goes through the interfacial region which separates them.

It is important to bear in mind that all or some of the potentiality factors and resistance coefficients can be affected by a sufficiently high curvature of the interfacial region, as well as by the variations of such curvature during malaxation.

In almost all the transfers where oil in elaboration intervenes, the rate of the transfer of each chemical species in a determined interfacial region will be a function of the time elapsed since the region was established, as well as of its position inside the olive paste. This behavior is due to the instantaneous values of the three parameters described above, which are functions of such time and such position.

\section{TRANSFERABLE CHEMICAL SPECIES}

Different types of chemical species can be transferred between the several systems present in olive-oil mills and the oil in elaboration. It should be taken into account that the magnitude of any transfer is a function of:

a) The chemical nature of the transferred species

b) The status of the olives when they leave the washing system prior to their crushing. Such status depends on genetic factors (olive cultivar), pedoclimatic factors (soil and climate), cultivation and irrigation techniques, as well as the degree of ripeness, the oil content and the moisture of the olives.

c) The way of conducting the operations in olive oil mill. Thus, an oil elaboration technology, which is suitable for olives of a determined cultivar, may be inadequate when dealing with another one.

It is of interest to remark that the variations produced by the transfers of minor components are very small in the global compositions of the systems that constitute the paste.

The main types of transferable chemical species will be considered next.

Type-A species - The initial non-glyceridic components of the recently crushed olive paste. These components include all the chemical species present in the paste that are not part of the cellular oil, regardless of their situation in the other systems of the paste (pulp, vegetation water and endocarp fragments).

The physical and colloidal characteristics of histological and cytological structures of the site where the initial non-glyceridic components were in the intact fruit prior to crushing can be very different from the characteristics of the site where such components are in the crushed paste. These characteristics change depending on the duration of their permanence in the already crushed paste.

Typical examples of initial non-glyceridic components which pass to the oil in elaboration are pigments (chlorophylls, xanthophylls, carotenes), phenolic derivatives and volatile compounds, which contribute to both the antioxidant capacity and sensorial quality of the resulting olive oil.

Chemical species constituents of the fruit cuticle, such as polycyclic triterpenes, waxes, and aliphatic alcohols and aldehydes, also pass to the oil in elaboration, in quantities that increase with the malaxation time.

Type-B species - These are species that were not originally present in the intact fruit before crushing, and which are generated by enzymatic and chemical processes (oxidations, hydrolysis, fermentations) taking place throughout the course of the elaboration of olive oil.

Upon olive crushing several enzymes become active and participate in diverse biochemical pathways. Their activities, which persist during the malaxation step, are the main cause of the changes in the characteristics of diverse analytical fractions of the virgin olive oil finally produced. 
The significance of these biochemical processes depends mainly on enzymatic levels, characteristic of each olive cultivar and depending on their genetic code, as well as some other factors exogenous to the paste itself.

A typical and remarkable case that should be mentioned is the transformation of complex molecules of secoiridoid glucosides, phenolic compounds abundant in olive fruits. These chemical species are hydrolyzed by glucosidases during crushing and malaxation. For example, oleoeuropein is converted into its aglycon derivative by the action of $\beta$-glucosidase, and the aglycon is split into hydroxytyrosol and elenoic acid by the action of an esterase.

In general, the concentration of total phenols and of o-diphenols in the paste and in the oil in elaboration decreases with malaxation time. A similar tendency is observed for the main free phenols (tyrosol and hydroxytyrosol) and their aglycon derivatives. These decreases are attributed to the activity of oxidases, such as lipoxygenase, which catalyzes the formation of fatty acids hydroperoxides, and can cause indirect oxidation of the secoiridoids.

Losses of phenolic compounds contribute to a decrease in the quality index of virgin olive oil, which is defined as the ratio between its positive and negative chemical attributes when referring to stability towards oxidation.

Another typical case is the formation of shortchain aldehydes and alcohols of five to nine carbon atoms, with those of six carbon atoms being the most abundant. These organic species, together with their acetyl esters, constitute the bulk of the volatile compounds responsible for the priced aroma of virgin olive oil.

These chemical species are produced from both linoleic and linolenic acids through a cascade of biochemical reactions known as the lipoxygenase pathway. This pathway is induced upon crushing and remains active during malaxation.

A third type of enzymatic process is the formation of undesirable volatile compounds by anaerobic fermentation, taking place during malaxation, of carbohydrates and amino acids. Deriving from hydroperoxide degradations, $n$-octane is also usually found.

Type-C species - Products resulting from solutions and reactions that can be originated in some of the solid surfaces of the tools and equipment used in the diverse operations of the olive oil mill. Because of the tools' cleanliness, the manual of good practices recommends that the oils elaborated at the beginning of the milling season should not be mixed with those produced in later operations.

Type-D species - The components of the exogenous water added to the paste in certain elaboration systems, like those of separation in a three-phase centrifugal decanter.
NOTE: The formation and transformation of chemical species of the types described so far can be affected by the addition of water to the paste.

Type-E species - The components of the air that are generally present in all the phases of the elaboration process.

The enzymatic processes, which have been described when dealing with type-B species, are generally favored by exposition of the paste to air during crushing and malaxation. A typical case is that of the lipoxygenase pathway, which is responsible for the formation of the volatile chemical species that constitute the aroma of virgin olive oil, which requires the presece of oxygen.

Oxygen in the air causes one of the most harmful effects on oil quality. Its reactions in the interfaces of the oil in elaboration with certain components of the paste usually provoke the formation of compounds which act as pro-oxidant for the unsaturated fatty chains. Thus performing the elaboration of oil in an atmosphere with low concentration of oxygen might contribute to a remarkable improvement of oil quality. All these effects due to oxygen depend on the degree of ripeness of the fruit.

Avoidable transfers and unavoidable transfers Undoubtedly, in every process of elaboration of virgin olive oil it should be considered:

a) Transfers that could be prevented, that is, those that are produced in portions of the paste in contact with solid surfaces of the equipment and tools involved in the elaboration of olive oil, water, light and air, as well as those produced by heating or cooling of the paste. The magnitude of some of these transfers can be reduced if the time of contact is reduced.

b) Transfers that can not be prevented without special treatment of the paste, that is, those taking place between its components as a consequence of biological, chemical and physical processes such as fermentation, enzymatic splitting, hydrolysis, diffusion, etc.

\section{TRANSFERS DURING CRUSHING}

During crushing, the equilibrium between the systems that integrate the physiological parts of the whole olive fruit (epicarp, mesocarp, endocarp and seed) is broken. The chemical species contained within them are mixed and distributed according to their affinity and concentration, among the different systems of the crushed paste defined above (oil in elaboration, free olive vegetation water, lipophilic laminar pulp, pseudo-colloidal pulp, and woody endocarp fragments).

When the cells of the oily parenchyma break down, it produces a sudden and very fast variation in the chemical and physical characteristics of the interfacial region of high curvature, separating the cellular oil from the initial non-glyceridic components of the fruits. 
A characteristic of the system highly modified upon disruption of the cells is the creation of a very extensive interfacial area. Through this area exist very high potentiality factors for the transferable chemical species of the paste that have solubility or a certain dispersion capacity in the oil in elaboration, since their initial concentration in this oil is zero.

Although the duration of the crushing is brief, the transports of transferable chemical species to oil droplets can be very significant. These transports will be more intense for amphiphilic chemical species on the outer surface of the membranes that surround the original droplets of the cellular oil. Therefore, shortly after the disruption of the oily parenchyma cells their content stops being cellular oil to become oil in elaboration. The paste also comes into contact with the surface of the crushing equipment (metals, silicates), as well as the ambient air of the olive-oil mill, which frequently is not as clean as it should be. The use of air conditioning surrounding this equipment could sometimes be satisfactory. In an ensemble of broken cells the variations, with time, of potentiality factor and resistance coefficient of each transferable chemical species greatly affect the rate of its transfer to the oil in elaboration. The physical structure and the degree of grinding of the paste, which are imparted by the crushing, are important factors for the establishment of the characteristics of the interfacial regions that are formed between the oil in elaboration and the other of systems of the paste.

\section{INTERFACIAL REGIONS BETWEEN THE OIL IN ELABORATION AND OTHER SYSTEMS OF THE PASTE DURING MALAXATION}

Malaxation of the olive paste is carried out in a stainless steel device made of a semi-cylindrical vat with a horizontal shaft, with rotating arms and blades of different shapes and sizes. This vat is equipped with a heating jacket with circulating hot water to warm the olive paste.

The efficiency of malaxation depends on the rheological characteristics of the olive paste and on the technological parameters of the operation, such as time and temperature.

During the malaxation of the paste, the droplets of the oil in elaboration, are forced to move among the other systems of the paste following the path imposed by the movement of the rotating blades. These droplets proceed from a single cell of the oleiferous parenchyma or are formed by coalescence of smaller droplets from different cells). This entails a continuous renewal of the interfacial regions, which modifies the rates of transfers through them.

Figure 3 corresponds to an olive paste where free oil and free olive vegetation water ("alpechín") are almost completely separated.

Figures 4 and 5 show simplified schemes of vertical cross-sections of a zone of the paste that

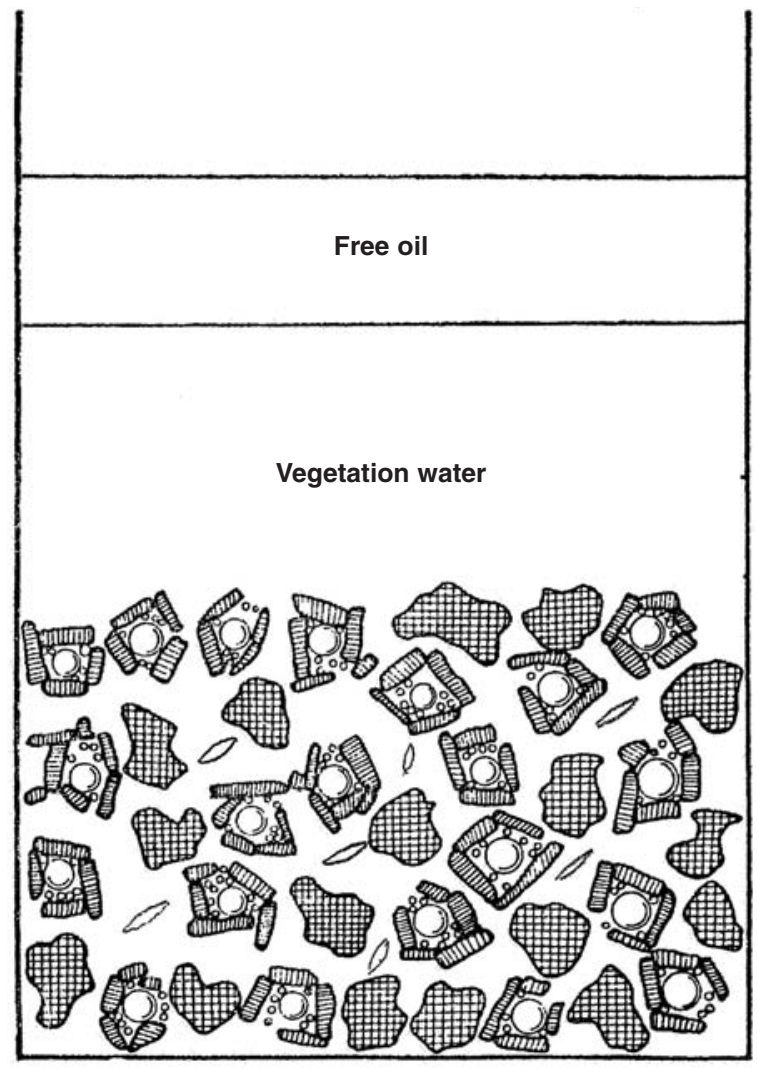

Figure 3

Simplified scheme of the structure of the paste at an intermediate phase of malaxation. At this point, continuous liquid phases of oil in elaboration and free olive vegetation water ("alpechín") are already separated.

contains continuous liquid phases of oil in elaboration, free olive vegetation water, woody endocarp fragments ("huesos"), micro-pseudo-gels of the pseudo-colloidal pulp, and portions of the lipophilic laminar pulp, during paste malaxation. This zone can be considered as intermediate between continuous liquid phases of oil in elaboration and free olive vegetation water ("alpechín").

In figure 4 such intermediate zone is situated in a region of the malaxated paste close to one of the rotating blades. The shearing effects push the micro-pseudo-gels and the fragments of lipophilic laminar pulp inside the continuous oily liquid phase of the oil in elaboration, meanwhile, the strongly hydrophilic woody endocarp fragments ("huesos") remain inside the continuous liquid aqueous phase of the free olive vegetation water ("alpechín").

Figure 5 corresponds to the same intermediate zone of the paste when it is situated far from the blades. The oil in elaboration does not contain woody endocarp fragments, or micro-pseudo-gels, because they are hydrophilic. The fragments of lipophilic laminar pulp, which are mainly lipophilic, are situated in the interfacial region between the continuous phases of the oil in elaboration and free olive vegetation water (alpechín). 


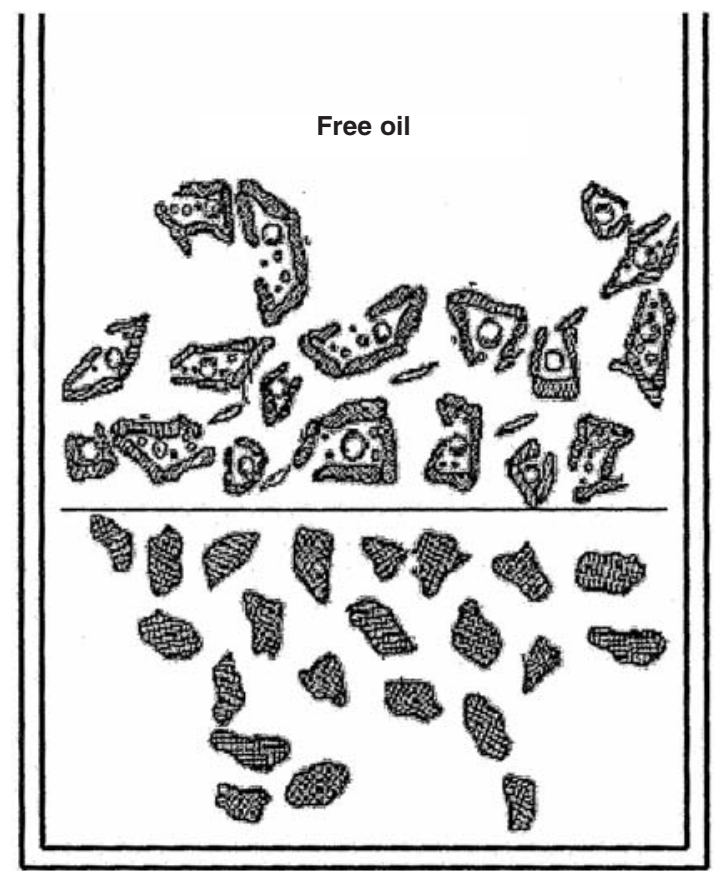

Figure 4

Simplified scheme of the situation of portions of woody endocarp fragments, micro-pseudo-gels and lipophilic laminar pulp during the malaxation of the paste, in a zone where continuous liquid phases of oil in elaboration and free olive vegetation water coexist. This zone is situated in a region of the malaxation vat close to one of its rotating blades.

The situation of figure 4 allows for the direct transfer or all the lipophilic components of both the micro-pseudo-gel and the lipophilic laminar pulp into the oil in elaboration.

In the situation of figure 5, on the other hand, no direct transfers of lipophilic components of the micropseudo-gel to the oil in elaboration will take place.

In the case of amphiphilic chemical species contained in micro-pseudo-gels (alcohols, phenols, aldehydes, esters), those with long chains will pass directly to the oil in elaboration in the situation of figure 4 . Those with short chains will pass to free olive vegetation water under the conditions of figure 5. Moreover, the transfers of phenolic compounds from the oil in elaboration to free olive vegetation water can be significant in the situation of figure 5 .

From what has been expounded in paragraphs and figures above we can infer that, during malaxation, because the shape of the beating blades, the time of direct contact between micropseudo-gels and the oil in elaboration will be much shorter than the periods they stay inside the olive vegetation water.

In reality, the interfacial regions situated between the oil in elaboration and the free olive vegetation water show varied and changing shapes during malaxation due to the continuous intervention of the blades. This behavior exerts a great influence over the thermodynamic and kinetic aspects that control the transfers of chemical species between the micro-pseudo-gels and the oil

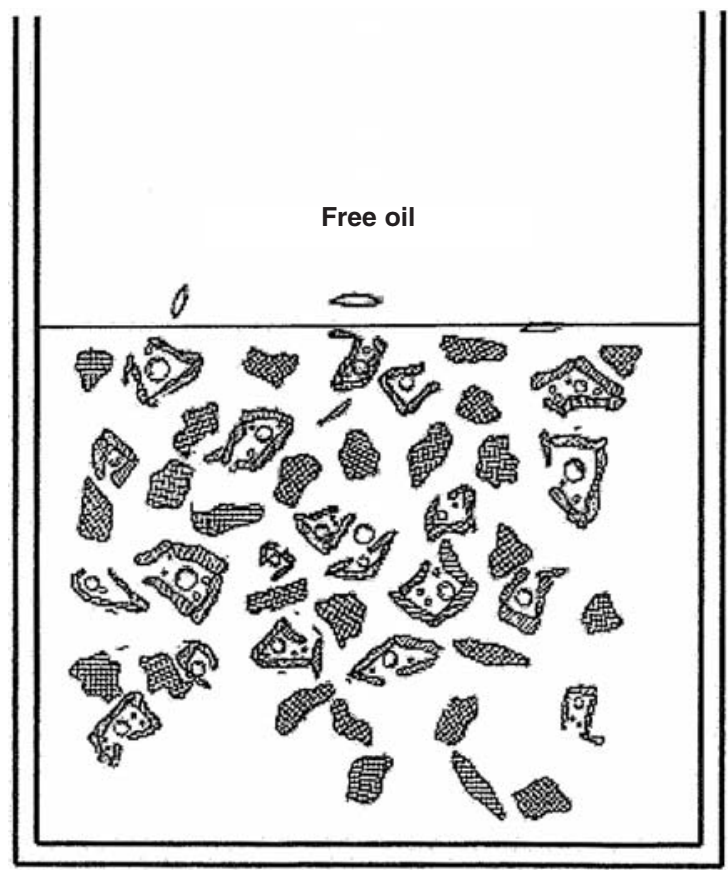

Figure 5

Simplified scheme of the situation of portions of woody endocarp fragments, micro-pseudo-gels and lipophilic laminar pulp during the malaxation of the paste, in a zone where continuous liquid phases of oil in elaboration and free olive vegetation water coexist. This zone in situated in a region of the malaxation vat far from its rotating blades.

in elaboration. Due to timing reasons, these transfers take place mainly during the permanence of micropseudo-gels in the aqueous environment, that is, with the intervention of free olive vegetation water.

It is important to remember that the separation, from a determined lot of olive fruits, of the oil in elaboration involves a gradual and considerable reduction in the total interfacial area initially existent between the droplets of cellular oil and the rest of the paste. The rate of this reduction will influence the concentration of minor components in the oil at the end of its elaboration.

A flocculation of droplets of the oil in elaboration produces a reversible reduction in its interfacial area with the other components of the paste, while the reduction produced by coalescence or disruption of emulsion is irreversible. The reduction in the interfacial area results in a clear decrease in the rate of transport of all the transferable chemical species. Consequently, the transfer of these species to all the droplets of flocculated oil in elaboration will be faster than the transfer to a single bigger drop with the same volume as the mentioned whole.

\section{TRANSFERS DURING MALAXATION}

In a whole of already broken cells, variations in the course of time of potentiality factors of each transferable chemical species noticeably affect the 
rate of transfer of the species between the oil in elaboration and the other systems of the paste at each moment.

For an initial non-glyceridic component, which is not altered during malaxation, the potentiality factor decreases continuously with time, because its concentration in the oil in elaboration increases whereas it decreases in the paste system where it initially was. This is the case of chlorophylls, xanthophylls and carotenes, as well as some lipophilic constituents of the epicarp.

The potentiality factor for a chemical species other than an initial non-glyceridic component varies with time as a function of the rate of the enzymatic or chemical process that generates it during malaxation. Such variation also depends on the rate of transfer of the species through the interfacial region between the oil in elaboration and the other systems of the paste.

Enzymatic processes taking place in the olive vegetation water can result in the variation (increase or decrease) of the content of certain chemical species in oil in elaboration. The following cases are typical:

An increase is produced when the concentration of the chemical species in the oil in elaboration at the start of the malaxation step is null or very low, and this partition coefficient between the oil and the olive vegetation water is very high. Thus, the pleasant and highly valued constituents of the aroma of virgin olive oil, which are formed from polyunsaturated fatty acids through the lipoxygenase pathway, increase their concentrations in the oil during the course of maxalation step. This behavior also occurs for unpleasant volatile compounds, produced by the fermentation of amino acids and carbohydrates or by the degradation of fatty acid hydroperoxides.

On the contrary, a decrease in the content of a chemical species in the oil in elaboration occurs it its concentrations in this oil at the beginning of the malaxation are high and the partition coefficient between oil and olive vegetation water is low. This is the case of some phenolic compounds present in the olive fruit, or that have been formed during crushing, which partition themselves between the oil in elaboration and olive vegetation water. The concentration of these chemical species in olive vegetation water decreases during malaxation due to certain chemical and enzymatic processes. To maintain the equilibrium dictated by the partition coefficient, phenolic compounds are transferred to olive vegetation water, thus decreasing their concentration in the oil in elaboration.

Quantification of the kinetics of transfer, between the oil in elaboration and the rest of the paste, for a determined chemical species is very difficult. Fundamental factors in this difficulty can be the total mass of paste undergoing malaxation and the "geometry", more or less semi-cylindrical, adopted by such mass inside the malaxation vat.

The rate of transfer of a chemical species during malaxation depends on many diverse factors. This explains why the results of experiments carried out at laboratory-scale that are found in the literature do not always coincide with those obtained in an industrial olive-oil mill.

Studies have been carried out to try to adjust the transfers of chemical species during the malaxation of the paste to simple kinetic equations. Essays on a large scale, performed with lots of $200 \mathrm{~kg}$ of olives, of three different cultivar varieties, with each paste submitted to malaxation for $0,15,30,45,60$ and 75 minutes at $30^{\circ} \mathrm{C}$, and finally centrifuged in a two-phase decanter, yielded the following results:

The variations with time of the contents of pigments (chlorophylls, xanthophylls and carotenes), as well as those of the so called "green" volatile compounds of six carbon atoms (products of the lipoxygenase pathway) adjust themselves, in a first approximation, to equations of the type:

$$
\mathrm{C}=\mathrm{C}_{0}[1-\exp (-\mathrm{kt})]+\mathrm{C}_{1}
$$

On other hand, the variations with time of the concentrations of phenolic compounds in a first approximation fit in an equation of the type:

$$
\mathrm{C}=\mathrm{C}_{0} \exp (-\mathrm{kt})
$$

The concentrations are expressed in milligrams per kilogram of oil, the time in minutes and the rate constants in minutes to the minus one. All constants depend considerably on the olive cultivar variety.

It is interesting to remark that for the transfers of pigments, whose presence does not depend directly on enzymatic processes, the values of velocity constants " $\mathrm{k}$ " for the three varieties are around $(3 \pm 0.7) 10^{-4} \mathrm{~min}^{-1}$.

In these studies, a continuous renewal of interfacial regions between the oil in elaboration and other paste systems can be admitted.

Consequently, the parameters A (geometry of interfacial region) and $C$ (resistance coefficient) of instantaneous rate of transfer thorough the interfacial region for each chemical species can remain within the same order of magnitude.

When malaxation finishes, the oil in elaboration should contain, at the adequate concentrations, essentially all the minor components determining the chemical and sensorial quality of the final virgin olive oil. All this depends on the characteristics of the process of oil elaboration, its duration and the temperature used.

As a preliminary conclusion, requesting confirmation by means of new studies, it can be established that, when working with a two-phase decanter, malaxation has a greater effect on the composition of the oil in elaboration than on the yield in virgin olive oil finally achieved.

The results of an experiment are shown below as a typical case. Yield values are expressed as percentages of oil separated in relation to the total oil content of the olives, whereas the concentrations of colorants (chlorophylls and pheophytines) are milligrams per kilogram of olive fruits.

$\begin{array}{lllllll}\text { Minutes of malaxation } & 0 & 15 & 30 & 45 & 60 & 75\end{array}$

Yield $\quad 81.382 .184 .787 .888 .487 .5$

$\begin{array}{lllllll}\text { Colorants } & 3.9 & 4.2 & 4.6 & 5.3 & 5.8 & 7.6\end{array}$ 
According to these data, during malaxation the oil yield reaches a maximum within approximately an hour, whereas the concentration of colorants keeps an increasing trend after that period.

It is currently known that the fruits of each olive cultivar require an adequate malaxation time, which depends on the histology and cytological characteristics of the paste. With pastes from unripe olives the malaxation can be extended up to 60 minutes, but with pastes from ripe olives this operation should not last more that 15 minutes. Temperature should not exceed $30^{\circ} \mathrm{C}$.

When the malaxation of the paste is too long, the excessive transfer of certain minor components imparts to it some characteristics of pomace olive oil (that obtained by solvent extraction and further refining from desiccated pomace). On the contrary, when malaxation is too short, the resulting oil contains smaller concentrations of volatile compounds which unfavorably affect its sensorial evaluation.

\section{TRANSFERS DURING THE SEPARATION OF VIRGIN OLIVE OIL}

Transfers in a centrifugal decanter - The time of permanence of the paste in a centrifugal decanter is too short to allow important transfers of minor components to the oil in elaboration. The nonspherical pockets of free oil decant almost instantaneously- The big oil drops located between the fragments of the micro-pseudo-gel framework move rapidly inside a heterogeneous system, whose rheological behavior can be compared to the one of a Bingham plastic fluid.

The velocity of oil separation is higher in threephase decanters than in a two-phase decanter, because in the first one the paste become more fluid as a consequence of the addition of exogenous water, thus reducing the proportion of pulp and woody endocarp fragments and hence its viscosity.

Transfers in percolators. - When the oil separation is carried out in a percolation system, the transfers of chemical species can be considered as continuation of those taking place during malaxation, although the concentration of oil in elaboration in the paste which remains in the percolator decreases successively with each entry of the blades into the paste.

Transfers in a press with filtering mats - If the oil is separated by pressing the paste between filtering mats, then the kinetics of transfer of chemical species are very different from those produced during malaxation.

The shear effects between the components of the paste, as well as between the paste and the wrinkled surface of the filtering mats, increase the renewal of interfacial regions between free oil and the other systems of the paste.

To summarize, it can be established that the oil in elaboration, aimed to be separated by centrifugation or percolation, at the end of the malaxation step, should show concentrations of minor components near to those desired in the final virgin olive oil. It is not necessary for the oils in elaboration to be separated by pressure.

Transfers during oil washing with water. After separation, the continuous phase of virgin oil is usually washed with water, and during this operation carried out by passive decanting or vertical centrifugation, transfers of minor components from the oil to the washing water can happen. Some of these transfers, whose potentiality factors can be very high can harm or improve the quality of the final oil, more or less noticeably, depending on the nature of the minor components involved.

In olive-oil mills equipped with two-phase centrifugal decanters, the oily phase after separation typically contains $97-98 \%$ of the virgin olive oil and $2-3 \%$ of solid impurities and vegetation water. To remove such impurities in a vertical centrifuge, a certain amount (in the range of $1: 1$ to $1,5: 1, \mathrm{v} / \mathrm{v}$ ) of water is generally added. This washing operation usually induces decreases in the oil content of phenolic compounds, stability towards oxidation and bitterness of the oil.

Transfers during the blending of diverse types of virgin olive oil to obtain a particular trademark.

The three or four types of virgin olive oil mixed to prepare a virgin olive oil of a certain trademark are different in both their solvent phase (triacylglycerols) and the chemical species dissolved in it (minor components). When making the mixture, the triacylglycerols and minor components of each virgin olive oil diffuse in a oily global medium whose composition varies with time, tending to that a physicochemical equilibrium which may take a considerable time to be reached. If such equilibrium is not reached, differences in the concentrations of triacylglycerols and minor components can produce differences in the sensorial characteristics in the content of the different bottles pertaining to the same lot of marketable blending.

\section{FINAL CONSIDERATIONS}

From what has been discussed in this review article, the possibility of improving the quality of the virgin olive oil resulting from a determined lot of olives by controlling the transfers of minor constituents to the oil in elaboration can be inferred. In fact:

1. The concentration in the oil in elaboration of a determined transferable chemical species depends on several factors. These are the composition (dictated by genetic characteristics) and ripeness of olives used for the elaboration of the oil, the extent and intensity of their crushing, the temperature and the time elapsed since the beginning of the transfer. 
2. The variations with time of the magnitude of some transfers depend, in turn, on the sort of changes with time of the rheological stresses applied to the paste during the successive steps (crushing, malaxation and separation) involved in the elaboration of the oil. These variations also depend on the action of the chemical and enzymatic processes that take place during such steps

3. If environment (atmospheric gases and vapours, olive-oil mill equipment and tools, washing waters, etc.) surrounding the oil since its original status of cellular oil until its bottling is adequate, then unfavorable transfers of exogenous minor components to the oil in elaboration should be minimal or null.

\section{ACKNOWLEDGEMENTS}

The author thanks sincerely Dr. Enrique Graciani Constante for the preparation of the figures appearing in this article. He also states his appreciation to Dr. Juan Sánchez for his valuable revision of the original text, especially to the biochemical aspects of the elaboration of virgin olive oil.

\section{REFERENCES}

Alba, J. 2001. Elaboración del aceite de oliva en Barranco, D., Fernández-Escobar, R., Rallo, L. (Eds.) El Cultivo del Olivo ,4a Ed.,581-587. Junta de Anadalucía/Mundi-Prensa, Madrid.

Alba, J., Martínez-Nieto, J. 2001. Elaboración de aceites de oliva en Mataix, J. (ed.) Aceite de oliva virgen: nuestro patrimonio alimentario, 43-61. Puleva Food/ Universidad de Granada, Granada.

Alba, J. 2004. Virgen extra, desde el árbol a la mesa en Guía Mercacei de los aceites de oliva virgen extra de España, 10-26. Edimarket Editores, S.L., Madrid.

Alba, J., Capogna, D., Martínez, F., Moyano, M.J., Hidalgo, F., Borja, R., Graciani, E., Ruiz, M.V. 2004. Elaboración del aceite de oliva virgen en Barranco, D., Fernández-Escobar, R., Rallo, L. (Eds.) El Cultivo del Olivo ,5를 Ed. 615-655. Mundi-Prensa, Madrid.

Amirante, P., Baccioni, L., Clodoveo, M.L. 2001. New tecnologies for olive oil. Folleto de Alfa-Laval SPA, Sambuca Val Di Pesa FI, Italy.

Amirante, R., Cini, E., Montel, G.L., Pasqualone, A. 2001. Influence of mixing and extraction parameters on virgin olive oil quality. Grasas y Aceites 52, 198-201.

Amirante, P., Dugo, G., Gomes, T. 2002. Influencia de la innovación tecnológica en la mejora de la calidad del aceite de oliva virgen extra. OLIVAE 39, 34-42.

Angerosa, F. 2002. Influence of volatile compounds on virgin olive oil quality evaluated by analytical approaches and sensor panels. Eur. J. Lipid Sci. Technol. 104, 639-660.

Aparicio, R., Luna, G. 2002. Characterization of monovarietal virgin olive oil. Eur. J. Lipid Sci. Technol. 104. 614-627.

Aparicio, R., Harwood, J. 2003. Manual del aceite de oliva. Editorial Mundi-Prensa, Madrid.
Baccioni, L. 2001. Extra Virgin Olive Oil. Folleto de AlfaLaval SPA, Sambuca Val Di Pesa FI, Italy.

Brenes, M., Hidalgo, F.J., García, A., Ríos, J.J., García, P., Zamora, R., Garrido, A. 2000. Pinoresinol and 1acetoxypinoresinol, two new phenolic compounds identified in olive oil. J. Am. Oil Chem. Soc. 77, 715720.

Brenes, M., Romero, C., García, A., Hidalgo, F.J., RuizMéndez, M.V. 2004. Phenolic compounds in olive oil intended for refining: Formation of 4-ethylphenol during olive paste storage. J. Agric. Food Chem. 54, 8177-8181.

Capogna, D., Costagli, G., Alba, J. 2001. El proceso de producción del aceite de oliva virgen. Comparación entre España e Italia. Agricultura 70, 784-788.

Caponio, F., Gomes, T., Summo, C., Pasqualone, A. 2003. Influence of the type of olive-crusher used on the quality of extra virgin olive oil. Eur. J. Lipid Sci. Technol. 105, 201-206.

Caponio, F., Pasqualone, A., Catalano, P., Gomes, T., Summo, C. 2004. Influenza della temperatura iniziale del frangitore sulla qualità degli oli extra vergine di oliva. Riv. Ital. Sost. Grasse 81, 19-22.

Dhifi, W., Maabaqui, B., Zitoan, B., Marzouk, B. 2002. Influence du système d'extraction sur la qualité organoleptique de l'huile d'olive de Tunisie. Riv. Ital. Sost. Grasse 79, 245-249.

Di Bella, G., Salvo, F., Bruzzese, A., Lo Turco, V., Dugo, G. 2004. Caratterizatione degli oli di oliva vergini siciliani. Nota XII. Livelli di contaminazione da pesticide organofosforici. Riv. Ital. Sost. Grasse 81, 148-151.

Di Giovacchino, L., Constantini, N., Ferrante, M.L., Serraiocco, A. 2002. Influence of maxalation time of olive paste on oil extraction yields and chemical and organoleptic characteristics of virgin olive oil obtained by a centrifugal decanter at water saving. Grasas $y$ Aceites 53, 179-186.

Di Giovacchino, L., Mucciarella, M.R., Constantini, M., Surricchio, G. 2002. Double oil extraction from olive paste and olive pomace by centrifugal decanter at 2phases, type integral, Riv. Ital. Sost. Grasse 79, 351 355.

Di Giovacchino, L., Sestili, S., Di Vicenzo, D. 2002. Influence of olive processing on virgin olive oil quality. Eur. J. Lipid Sci. Technol. 104, 587-601.

Dugo, G., Lo Curto, S., Lo Turco, V., La Torre, L., Salvo, F. 2002. Valutazione del contenuto di $\mathrm{Cu}(\mathrm{II}), \mathrm{Zn}(\mathrm{II})$, $\mathrm{Cd}(\mathrm{II})$ e $\mathrm{Pb}$ (II) in oli di oliva prodotti nella Valle del Belice. Riv. Ital. Sost. Grasse 79, 157-160.

El Antari, A., El Moudni, A., Ajana H. 2003. Comparación de la composición acídica del aceite de algunas variedades mediterráneas cultivadas en Marruecos. Olivae 95, 26-31.

El Antari, A., El Moudni, A., Ajana, H. and Cert, A. 2003. Lipid composition of two fruits parts (flesh and kernel) of six varieties of olive tree cultivated in Morocco. Olivae $98,20-28$.

Fiorino, P. 2003. Olea; tratato di olivicultura, 264-280. Edagricole, Bologna..

Frega, N., Strabbioli, R., Borselli, E., Pacetti, D., Romagnoli, E. 2003. Caracterizzatione chimica e sensoriale dell'olio estratto della cultivar Leccino in funzione deIla tecnologia e della gramolatura. Riv. Ital. Sost. Grasse $\mathbf{8 0}, 71-80$.

Frega, N.G., Caglioti, L., Strabbioli, R., Bocci, E. 2005. Stabilità dell'olio extravergine ottenuto da olive denocciolate. Riv. Ital. Sost. Grasse 82, 55-58.

Gallardo-Guerrero, M.L., Roca López-Cepero, M.G., Mínguez-Mosquera, M.I. 2002. Distribution of chorophylls 
and carotenoids present in the olive, between oil and alperujo (System of two-phases extraction). J. Am. Oil Chem. Soc. 79, 105-109.

García, A., Brenes, M., Martínez, F., Alba, J., García, P., Garrido. A. 2001. High-Performance chromatography evaluation of phenols in virgin olive oil during extraction at laboratory and industrial scale. J. Am. Oil Chem. Soc. 78, 625-629.

García, A., Brenes, M., Moyano, M.J., Alba, J., García, P. Garrido. A. 2001. Improvement of phenolic compound content in olive oil by using enzimes during malaxation. J. Food Eng. 48, 189-194.

García, A., Brenes, M., Romero, C., García, P., Garrido, A. 2002. Study of phenolic compounds in virgin olive oil of the Picual variety. Eur. Food Res. Technol. 215, 407-412.

García Borrego, A., Brenes Balbuena, M., Romero Barranco, C., García García, P., Garrido Fernández, A. 2003. Los polifenoles del aceite de oliva, al descubierto. Oleo 96, 59-68.

García-González, D.L., Aparicio, R. 2003. Virgin olive oil quality, classification combining neural network and MOS sensors. J. Agr. Food Chem. 51, 3515

García-González, D.L., Aparicio, R. 2004. Classification of different quality virgin olive oil by metal-oxide sensors. Eur. Food Res. Technol. 218, 484-487.

García-González, D.L., Barie, N., Rapp, M., Aparicio, R. 2004. Analysis of virgin olive oil volatiles by a novel electronic nose based on a minituarized SAW sensor array coupled with SPME enhanced headspace enrichment. J. Agric. Food Chem. 52, 7475-7479.

Gimeno, E., Castellote, A.I., Lamuela-Raventos, R.M., De La Torre, M.C., López-Sabaté, M.C. 2002. The effect of harvest and extraction methods on the antioxidant content (phenolics, $\alpha$-tocopherol and $\beta$-carotene) in virgin olive oil. Food Chem. 78, 207-211.

Giuffré, A.M. 2002. Gli oli di oliva vergine pugliesi: La Peranzana nella provincia de Foggia. Influenza dell'epoca di raccolta e dei processi tecnologici di estrazione sulla qualità dell'olio. Nota I: la estabilità biologica. Riv. Ital Sost. Grasse 79, 343-349.

Giuffré, A.M. 2003. Gli oli di oliva vergine pugliesi: La Peranzana nella provincia de Foggia. Influenza dell'epoca di raccolta e dei processi tecnologici di estrazione sulla qualità dell'olio. Nota II: colore, acidi grassi e steroli. Riv. Ital. Sost. Grasse 80, 11-20.

Gomes, T., Caponio, F., Delcuratolo, D., Bilancia, M.T. 2002. La classi di sostanze di ossidazione, polimerizzazione ed idrolisi dell'olio di oliva. Loro impiego neIl'accertamiento di qualità. Riv. Ital. Sost. Grasse 79, 211-214.

Guinda, A., Albi, T., Lanzón, A. 2000. Preparación de aceites de oliva enriquecidos en sus propios componentes minoritarios. Información Tecnológica 11, 6166.

Gutiérrez, F., Varona, L., Albi, M.A. 2000. Relation of acidity and sensory quality with sterol content of olive from stored fruit. J. Agric. Food Chem. 48, 1106-1110.

Gutiérrez-Rosales, F., Ríos, J.J., Gómez-Rey, Mª.L. 2003. Main polyphenols in the bitter taste of virgin olive oil. Confirmation of on-line chromatography electrospray ionization mass spectrometry. J. Agric. Food Chem. 51, 6021-6025.

Gutiérrez, F., Villafranca, M.J., Castellano, J.M. 2002. Changes of the Main Components and Quality Indexes of Virgin Olive Oils during Oxidation. J. Am. Oil Chem. Soc. 79, 669-676.

Hardwood, J., Aparicio, R. 2000. Handbook of Olive Oil. Aspen Publishers, Gaithersbury, Maryland.
Harwood, J.L., Yaqoob, P. 2002. Nutritional and health aspects of olive oil, Eur. J. Lipid Sci. Technol. 104, 685697.

Hidalgo, F.J., Alaiz, M., Zamora, R. 2001. Determination of peptides and proteins in fat and oils. Anal. Chem. 73, 698-702.

Hidalgo, F.J., Alaiz, M., Zamora, R. 2002. Low Molecular Weight Polypeptides in Virgin and Refined Olive Oils. J. Am. Oil Chem. Soc. 79, 685-689.

Jiménez, A., Rodríguez, R., Fernández-Caro, L., Guillén, R., Fernández-Bolaños, J., Heredia, A. 2001. Olive fruit cell wall: degradation of pectic polysaccharides during ripening. J. Agric. Food Chem. 49, 409-415.

Jiménez, A., Rodríguez, R., Fernández-Caro, L., Guillén, R., Fernández-Bolaños, J., Heredia, A. 2001. Olive fruit cell wall: degradation of cellulosic and hemicellulosic polysaccharides during ripening. J. Agric. Food Chem. 49, 2008-2013.

Kiritsakis, A., Kanavouras, A., Kiritsakis, A. 2002. Chemical Analysis, quality control and packaging issues of olive oil. Eur. J. Lipid Sci. Technol. 104, 628-638.

Luaces, P., Pérez, A.G., Sanz, C. 2003. Role of olive seed in the biogenesis of virgin olive oil aroma. J. Agr. Food Chem. 51, 4741-4745.

Luaces, P., Pérez, A.G., Sanz, C. 2004. Efecto del deshuesado de la aceituna sobre el aroma del aceite de oliva virgen. Grasas y Aceites 55, 174-179.

Mateos, R., Cert, A., Pérez-Camino, M.C., García, J.M. 2004. Evaluation of virgin olive oil bitterness by quantification of secoiridoid derivatives. J. Am. Oil Chem. Soc. 81, 71-75.

Montedoro, G.F., Baldioli, M., Selvaggini, R., Begliomini, A.L., Taticchi, A., Servili, M. 2002. Relationships between phenolic composition of olive fruit and olive oil; the importantce of endogenous enzymes. Acta Horticulture 586, 551-556.

Moreda, W., Rodríguez-Acuña, R., Pérez-Camino, M.A., Cert, A. 2004. Determination of heavy polyclic aromatic hydrocarbons in refined olive pomace oil and other vegetable oils. J. Sci. Food Agric. 84, 1759-1764.

Ortega Jurado, A., Palomar Carnicero, J.M., Cruz Peragón, F. 2004. Elaboración integral de las aceitunas con autogeneración de electricidad, comparada con el sistema actual de obtención del aceite de oliva virgen. Grasas y Aceites 55, 0303-311.

Pardo, J.E., Pérez, J.I., Andrés, M., Alvarruiz, A. 2002. Aplicación del sistema de análisis y peligros y puntos de control crítico (APPCC) en la línea de elaboración del aceite de oliva virgen. Grasas y Aceites 53, 309-318.

Parenti, A., Spugnoli, P. 2002. Influenza della temperatura delle paste di oliva sul contenuto polifenolico degli oli estratti. Riv. Ital. Sost. Grasse 79, 97-100.

Parenti, A., Spugnoli, P., Masella, P., Calamai, L. 2005. Utilizzo dell'anidride carbonia emessa dalle paste di oliva durante la trasformazione per migliorare la qualità dell'olio. Primo contributo. Prove di laboratorio. Riv. Ital. Sost. Grasse 82, 283-290.

Pérez, A.G., Luaces, P., Ríos, J.J., García, J.M., Sanz, C. 2003. Modification of volatile compound profile of virgin olive oil due to water-heat tratments on olive fruit. J. Agr. Food Chem. 51, 6544-6549.

Pérez-Camino, M.C., Moreda, W., Cert. A. 2001. Effects of olive fruit quality and oil storage practices on the diacylglycerol content of virgin olive oils. J. Agric. Food Chem. 49, 699-704.

Pérez-Camino, M.C., Moreda, W., Mateos, R,, Cert, A. 2002. Determination of esters of fatty acids with low molecular weight alcohols in olive oils. J. Agr. Food Chem. 50, 4721-4725. 
Poilana, M., Mincione, A. 2004. Fatty acids evolution and composition of olive oils extracted from different olive cultivars grown in Calabrian area. Grasas y Aceites 55, 282-290.

Psomiadou, E., Konstantinos, X., Blekas, G., Tsimidou, M.Z., Boscou, D. 2003. Proposed parameters for monitoring quality of virgin olive oil. Eur. J. Lipid Sci. Technol. 105,403-408.

Ranalli, A., Pollastri, L., Contento, S., Iannucci, E., Lucera, L. 2003. Effect of olive paste kneading process time on the overall quality of virgin olive oil. Eur. J. $\mathrm{Li}$ pid Sci. Technol. 105, 57-67.

Ranalli, A., Lucera, L., Contento, S., Simone, N., Del Re, P. 2004. Bioactive constituents, flavors and aromas of virgin oils obtained by processing olives with a natura enzyme extract. Eur. J. Lipid Sci. Technol. 106, 187197.

Roca, L., Cepero, M., Mínguez-Mosquera, M.I. 2001. Change in the natural ratio between chlorophylls and carotenoids in olive fruit during processibg for virgin olive oil. J. Am. Oil Chem. Soc. 78, 133-138.

Roca, M., Gandul-Rojas, B., Gallardo-Guerrero, L., Mínguez-Mosquera, M.I. 2003. Pigment parameters determining Spanish virgin olive oil autheticity. Stability during storage. J. Am. Chem. Soc. 80, 137-1240.

Roca, M., Mínguez-Mosquera, M.I. 2003. Involvement of chlorophyllase in chlorophyll metabolism in olive varieties with high and low chlorophyll content. Physiol. Plantarum 117, 459-466.

Romano, R., Di Micco, V., Aronne, G. 2004. Caratteristiche istologiche e citologiche dei frutti di alcune cultivar di olivo. Riv. Ital. Sost. Grasse 81, 73-79.

Romero, C., Brenes, M., García, P., Garrido, A. 2002. Hydroxytyrosol 4- $B-D-$ glucoside, an important phenolic compound in olive fruits and derived products. $J$. Agr. Food Chem. 50, 3835-3839.

Rovellini, P., Cortesi, N., Mattei, A., Marotta, F. 2002. Composti carbonilici volatili nell'aroma dell'olio vergine di oliva. Riv. Ital. Sost. Grasse 79, 429-438.

Rovellini, P., Cortesi, N. 2003. Evolución de los compuestos fenólicos en distintos cultivares durante la maduración del fruto. Olivae 95, 32-38.

Rovellini, P. 2004. Indice di qualità dell'olio extra vergine di oliva, antiossidante naturali e stato di ossidazione. Riv. Ital, Sost. Grasse 81, 335-341.

Ruiz-Méndez, M.V., Ramos Hinojosa, A.E. 2003. Fatty acid esters with short chain alcohols in two-phase olive pomace oil. Eur. J. Lipid Sci. Technol. 105, 346-350.

Salas, J.J., Sánchez, J., Ramli, U.S., Manaf, A.M., Williams, M., Harwood, J.L. 2000. Biochemistry of lipid metabolism in olive and other oil fruits. Progr. Lipid Res. 39, 151-180.
Salas, J.J. 2004. Characterization of acyl transferase from olive fruit. J. Agr. Food Chem. 52, 3155-3158.

Sánchez, J., Harwood, J.L. 2002. Biosynthesis of triacylglycerols and volatiles in olives. Eur. J. Lipid Sci. Technol. 104, 564-573.

Scano, P., Saba, G., Lai, A., Bendino, G., Deiano, M., Dessi, M.A. 2005. A study of Sardinian olive oils based on the content of unsaturated fatty acids and minor components. Riv. Ital. Sost. Grasse 82, 1-5.

Servili, M., Montedoro, G.F. 2002. Contribution of phenolic compounds to virgin olive oil quality. Eur. J. Lipid Sci. Technol. 104, 602-613.

Servili, M., Selvaggini, R., Baldioli, M., Taticchi, A., Esposto, S., Montedoro, G.F. 2002. Effect of time of exposure to the air contact of olive pastes during mechanical extraction process on the volatile and phenolic compounds of virgin olive oil. Innovation in virgin olive oil processing. Riv. Ital. Sost. Grasse 79, 439-441.

Servili, M., Selvaggini, R., Baldioli, M., Taticchi, A., Esposto, S., Montedoro, G.F. 2003. Volatile compounds and phenolic composition of virgin olive oil; optimization of temperature and time exposure of olive pastes to air contact during the mechanical extraction. $J$. Agric. Food Chem. 51, 7980-7988.

Vekiari, S.A., Koutsaftakis, A. 2002. The effect of different processing stages of olive fruit on the extracted olive oil polyphenol content. Grasas y Aceites 53, 304-308.

Vekiari, S.A., Papadopoulou, P., Koutsaftakis, A. 2002. Comparison of different olive oil extraction systems and the effect of storage conditions on the quality of the virgin olive oil. Grasas y Aceites 53, 234-239.

Velasco, J., Dobarganes, C. 2002. "Oxidative stability of virgin olive oil. Eur. J. Lipid Sci. Technol. 104, 661-676.

Vierhuis, E., Servili, M., Daldioli, M., Schols, A., Voragen, A.G.J., Montedoro, F.G. 2001. Effect of enzyme treatment during mechanical extraction of olive oil phenolic compounds and polysaccharides. J. Agric, Food Chem. 49, 1218-1223.

Visioli, F., Galli, C., Galli, G., Caruso, D. 2002. Biological activities and metabolic fate of olive oil phenols. Eur. J. Lipid Sci. Technol. 104, 677-684.

Zunin, P., Boggia, R., Rossi, N., Evangelisti, F., Tiscornia, E. 2001. Progetto Regione Liguria per il "Miglioramento qualitativo dell'olio di oliva ligure". Risultati di due anni di sperimentazione (1997-1998). Riv. Ital. Sost. Grasse 78, 17-23. 